\title{
MANAGEMENT OF PATIENTS WITH CHRONIC ATRIAL FIBRILLATION
}

\author{
P. SALHADIN, M. BRAN, M. DE MARNEFFE \& H. DENOLIN \\ Laboratoire de Physiologie Cardiopulmonaire - Université Libre de Bruxelles, Belgium
}

Circadian heart rate curves recorded by Holter monitoring in patients with chronic atrial fibrillation show that their medical management is often inadequate.

Either the ventricular response rate is too high during both day and night; or it may be very low during sleep, but too high during the day with reference to the physical activities performed by the patient. Sometimes, the heart rate remains too low during the whole circadian cycle. Such findings suggest the need for therapeutic intervention.

As conduction in the atrio-ventricular node controls ventricular response rate in the case of atrial fibrillation (any ventricular ectopic activity excepted), it is possible to alter this rate with drugs that modify atrio-ventricular conductivity.

Digitalis has been used for this indication for many years, but $\beta$-adrenoceptor blocking drugs are also widely prescribed.

In order to re-evaluate the action of these drugs, we have studied the effect on ventricular response rates of digitalis and of two $\beta$-adrenoceptor blockers, one (propranolol) without intrinsic sympathomimetic activity (ISA) and the other (pindolol) with relatively pronounced ISA.

Three groups of patients (aged 43 to 80 years) with chronic atrial fibrillation of various aetiologies (valvular prostheses, different types of valve disease, corrected septal-atrial defect, ischaemic or idiopathic cardiopathy) were studied. All patients except one were receiving cardiac glycoside therapy prior to entry in the study, but none of them was taking any other drug known to have an effect on atrioventricular conduction. No patient showed any sign of congestive heart failure, or marked cardiomegaly.

In the first group of 10 patients (group 1), the dose of the previous digitalis therapy (digitoxin, digoxin, methyldigoxin) was increased.

In the second group of 11 patients (group 2), digitalis dose remained unchanged and propranolol, 20 to $40 \mathrm{mg}$ three times daily was added. In the third group of 10 patients (group 3), digitalis dose remained unchanged and pindolol, 2.5 to $5 \mathrm{mg}$ three times daily, was added to the treatment regimen.

A Holter monitoring record was made (by MEDILOG I or II recorder) before and after the modification of therapy. The second record usually took place 2 weeks after the first one.

The ventricular response rate curves were performed by a Pathfinder analyser with an ST-module (Reynolds Medical). On these curves (time constant $9 \mathrm{~s}$ ), the maximal and minimal analogue rates, the mean diurnal rate and the lowest mean nocturnal rate for three consecutive hours were measured. Also using the analyser the shortest period of ten consecutive heart cycles (maximal rate on ten cycles), and the

Table 1 The results (mean \pm s.d.) of the study. HR heart rate (beats/min)

\begin{tabular}{|c|c|c|c|c|c|c|}
\hline & \multicolumn{2}{|c|}{$\begin{array}{l}\text { Increasing the dose of } \\
\text { digitalis group } 1 \\
(\mathrm{n}=10)\end{array}$} & \multicolumn{2}{|c|}{$\begin{array}{c}\text { Digitalis }+ \text { propranolol } \\
\text { group } 2 \\
(\mathrm{n}=11)\end{array}$} & \multicolumn{2}{|c|}{$\begin{array}{c}\text { Digitalis }+ \text { pindolol } \\
\text { group } 3 \\
(\mathrm{n}=10)\end{array}$} \\
\hline & Before & After & Before & After & Before & After \\
\hline Maximum HR ( 10 beats) & $\begin{array}{c}157 \\
( \pm 24)\end{array}$ & $\begin{array}{c}145 \\
( \pm 24)\end{array}$ & $\begin{array}{c}177 \\
( \pm 22)\end{array}$ & $\begin{array}{c}132 \\
( \pm 26)\end{array}$ & $\begin{array}{c}173 \\
( \pm 20)\end{array}$ & $\begin{array}{l}134 \\
( \pm 26)\end{array}$ \\
\hline Analogue maximum $\mathrm{HR}$ & $\begin{array}{c}147 \\
( \pm 21)\end{array}$ & $\begin{array}{c}138 \\
( \pm 19)\end{array}$ & $\begin{array}{c}155 \\
( \pm 23)\end{array}$ & $\begin{array}{c}123 \\
( \pm 23)\end{array}$ & $\begin{array}{c}152 \\
( \pm 18)\end{array}$ & $\begin{array}{l}120 \\
( \pm 19)\end{array}$ \\
\hline Mean diurnal HR & $\begin{array}{c}99 \\
( \pm 16)\end{array}$ & $\begin{array}{c}88 \\
( \pm 14)\end{array}$ & $\begin{array}{c}102 \\
( \pm 17)\end{array}$ & $\begin{array}{c}78 \\
( \pm 14)\end{array}$ & $\begin{array}{c}106 \\
( \pm 17)\end{array}$ & $\begin{array}{r}86 \\
( \pm 16)\end{array}$ \\
\hline Mean nocturnal (3 h) HR & $\begin{array}{c}71 \\
( \pm 11)\end{array}$ & $\begin{array}{c}61 \\
( \pm 9)\end{array}$ & $\begin{array}{c}69 \\
( \pm 15)\end{array}$ & $\begin{array}{c}60 \\
( \pm 13)\end{array}$ & $\begin{array}{c}59 \\
( \pm 11)\end{array}$ & $\begin{array}{r}70 \\
( \pm 13)\end{array}$ \\
\hline Analogue minimum $\mathrm{HR}$ & $\begin{array}{c}58 \\
( \pm 10)\end{array}$ & $\begin{array}{c}47 \\
( \pm 10)\end{array}$ & $\begin{array}{c}55 \\
( \pm 14)\end{array}$ & $\begin{array}{c}47 \\
( \pm 12)\end{array}$ & $\begin{array}{c}46 \\
( \pm 9)\end{array}$ & $\begin{array}{r}56 \\
( \pm 13)\end{array}$ \\
\hline $\begin{array}{c}\text { Virtual minimum HR } \\
\text { (10 longest cycles) }\end{array}$ & $\begin{array}{c}33 \\
( \pm 8)\end{array}$ & $\begin{array}{c}28 \\
( \pm 7)\end{array}$ & $\begin{array}{l}30 \\
( \pm 7)\end{array}$ & $\begin{array}{c}26 \\
( \pm 5)\end{array}$ & $\begin{array}{l}25 \\
( \pm 4)\end{array}$ & $\begin{array}{c}32 \\
( \pm 5)\end{array}$ \\
\hline
\end{tabular}

$0306-5251 / 82 / 130295-02 \$ 01.00$ 
ten longest cardiac cycles were obtained: by averaging them, a virtual frequency (virtual minimal heart rate), which is of course higher than the minimal rate measured beat by beat, was calculated.

The results are shown in Table 1.

Before any change in medication, the three groups were similar except for the maximal heart rates on ten cycles, which was significantly lower in group 1 than in the two other groups. The initial nocturnal heart rates were significantly lower in the group 3 .

Diurnal heart rates were lowered in all three groups, but the fall was significantly less after increasing the dose of digitalis (group 1) than after administration of either $\beta$-adrenoceptor blockers (groups 2 and 3 ). Despite the higher initial rates, the frequencies became lower in the pindolol and propranolol groups than in the digitalis alone group.

The nocturnal rates were lowered in the digitalis alone and propranolol group (group 2), whereas addition of pindolol increased the nocturnal rates.

Digitalis exerts a vagomimetic action and lowers only slightly high diurnal rates induced by the ad- renergic system during physical activity. On the other hand, its negative chronotropic activity appears mainly during the night.

The $\beta$-adrenoceptor blockers tested, despite their different properties, have a more marked, and similar, lowering action on the diurnal frequencies.

During the night, $\beta$-adrenoceptor blockers without ISA lower the heart rate by blocking the nocturnal sympathomimetic activity, which is usually very weak. On the contrary, $\beta$-adrenoceptor blockers with ISA substitute this activity for the very weak adrenergic tone during the night, so raising the nocturnal rates.

ISA demonstrated on the sinus receptor when the patient is in sinus rhythm (Leclercq et al., 1980), becomes perceptible on atrio-ventricular conductivity when the patient is in atrial fibrillation by similar changes in the pattern of cardiac rates, i.e. a lowering of the high rates achieved during physical activity, and an increase in the lowest rates observed when the adrenergic tone is weak.

\section{Reference}

LECLERCQ, J.F., ROSENGARTEN, M.D., ATTUEL, P., KURAL, S., MILOSEVIC, \& COUMEL, P.H. (1980). Les effets des antiarrhythmiques sur le rhythme sinusal. Arch. Mal. Coeur., 73, 903-911. 